\title{
Determinants of Job Satisfaction in the Spanish Wood and Paper Industries: A Comparative Study across Spain
}

\section{Odrednice zadovoljstva poslom u španjolskoj drvnoj i papirnoj industriji: komparativna studija s tržištem rada u Španjolskoj}

Preliminary paper • Prethodno priopćenje

Received-prispjelo: 21. 2. 2017.

Accepted-prihvaćeno: 21. 2. 2018.

$U D K: 630 * 79$

doi:10.5552/drind.2018.1711

\begin{abstract}
This paper analyses job satisfaction of a group of workers in the logging, wood and paper industries and results were compared with the entire Spanish labor market. Fourteen quantitative variables of jobrelated features were selected. For this purpose, data from the Quality of Labor Life Survey (Encuesta de calidad de vida en el trabajo - ECVT) administered by the Spanish Ministry of Employment and Social Security was used. The first objective was to find relationships between the 14 variables that were involved, and make associations and classifications between them via statistical methods. Secondly, the effects of six new variables that resulted from the above groups on a labor satisfaction variable were investigated. The analysis in both groups allowed a comparison to see if the conclusions were the same or different according to activity. In both cases, wage was one of the last factors that explained labor satisfaction, whereas motivation and personal development ranked first.
\end{abstract}

Keywords: job satisfaction, wood and paper industry, motivation, salary, personal development

SAŽETAK・U radu se analizira zadovoljstvo poslom skupine radnika u iskorištavanju šuma te u drvnoj i papirnoj industriji, a rezultati su uspoređeni s podatcima za cijelo tržište rada u Španjolskoj. Odabrano je 14 kvantitativnih varijabli vezanih za obilježja posla. Za tu namjenu korišteni su podatci iz Ankete o kvaliteti života na radu (Encuesta de calidad de vida en el Trabajo - ECVT) koje administrira španjolsko Ministarstvo zapošljavanja $i$ socijalne sigurnosti. Prvi cilj istraživanja bio je pronaći povezanost između 14 varijabli uključenih u analizu te formirati skupine i provesti klasifikaciju među njima primjenom statističkih metoda. Drugi je cilj bio istražiti učinke šest novih varijabli nastalih od formiranih skupina varijabli zadovoljstva poslom. Analiza varijabli zado-

\footnotetext{
${ }^{1}$ Author is senior lecturer at Universidade da Coruña, Department of Applied Economics, Faculty of Economics and Business Administration, A Coruña, Spain. ${ }^{2}$ Author is senior lecturer, Universidad de Zaragoza, Department of Business Administration, School of Engineering, Zaragoza, Spain. ${ }^{3}$ Authors are senior lecturers, Universidad de Vigo, Department of Business Administration, Faculty of Business Administration and Tourism, Orense, Spain.

Autorica je viša predavačica Sveučilišta u Coruñi, Fakultet ekonomije i poslovne administracije, Odjel za primijenjenu ekonomiju, A Coruña, Španjolska. ${ }^{2}$ Autor je viši predavač Sveučilišta u Zaragozi, Tehnički fakultet, Zavod za poslovnu administraciju, Zaragoza, Španjolska. ${ }^{3}$ Autori su viši predavači Sveučilišta u Vigu, Fakultet za poslovno upravljanje i turizam, Zavod za poslovnu administraciju, Orense, Španjolska.
} 
voljstva poslom u obje skupine podataka omogućuje usporedbu kako bi se vidjelo jesu li zaključci prema aktivnostima bili jednaki ili različiti. Analizom obiju skupina podataka dobiven je rezultat da je plaća jedan od posljednjih čimbenika koji utječu na zadovoljstvo poslom, a motivacija i osobni razvoj bili su na prvome mjestu.

Ključne riječi: zadovoljstvo poslom, drvna i papirna industrija, motivacija, plaća, osobni razvoj

\section{INTRODUCTION}

\section{UVOD}

The origin of the analysis of job satisfaction as an important variable in the study of human resources and organizational behavior arose from Hoppock, who wrote the book Job Satisfaction in 1935. This contribution attempted to demonstrate the relevance of job satisfaction and its positive effect on labor productivity. Job satisfaction can be studied from many different approaches and empirical models, and involves focusing on worker features, job circumstances or a combination of both. Job satisfaction is influenced by multiple variables, which all have different relevance.

The Van Der Meer and Wielers (2013) model studied job characteristics, motivation, and their effects on job satisfaction. Similarly, this study included, as independent variables, job-related features, because it was assumed that job-related features were the best for predicting job satisfaction (Sánchez-Sellero et al., 2014). Other studies that support this theory are: Dueñas et al. (2010), who proposed the low explanatory power of personal variables on job satisfaction, and Robles-García et al. (2005), who showed that satisfaction was strongly associated with a positive valuation of job-related features.

Guest and Conway (2002) found a positive relationship between the organizational communication and concepts such as job satisfaction, organizational commitment, motivation, and the positive evaluation of employment relationships. Cequea and Núñez Bottini (2011) showed that productivity was affected by motivation, job satisfaction, participation, and labor climate, among others. Different studies proposed a complex relationship of psychosocial factors and motivation, not only with positive business outcomes through a better performance of workers (Grant and Sumanth, 2009), but also with workers' well-being (Rego et al., 2009).

Some models developed by Cuadra-Peralta and Veloso-Besio (2010) and Bòria-Reverter et al. (2012) studied the relationship between the job environment and job satisfaction, including variables, such as job features, organizational climate, and social information, as the basic motivators of job satisfaction. Cuadra-Peralta and Veloso-Besio (2010) showed that a good working atmosphere was related to appropriate organizational functioning. Bòria-Reverter et al. (2012) analyzed the possible relations between salary, different intangible assets, and job satisfaction in organizations. Chiang Vega et al. (2010) reported that job satisfaction was important to organizational behavior. Job satisfaction and dissatisfaction were associated with organizational indicators, such as performance quality, etc. Judge et al. (2001) made a qualitative and quantitative review of the relationship between job satisfaction and job performance.
Job motivation is a personal stimulus that directs behavior, for better or for worse, in the workplace. Pérez (1997) studied different approaches around motivation and job satisfaction based on orientations, aspirations, and expectations of workers, from a historical-sociological perspective. Kanfer (1995) pointed out that motivation and performance had a reciprocal influence, because motivation can affect performance, and performance can affect motivation. Research results of Alnıçık et al. (2012) showed that motivation had a positive correlation with organizational commitment and job satisfaction. A recent study by Shah et al. (2016) identified some of the factors that affected job motivation (adequate remuneration, good job environment, etc.).

"The model of job satisfaction determinants", proposed by Lawler (1973), focused on the relationship of "expectations-rewards" from different aspects of a job. The relationship between expectation and reward can lead to job satisfaction or dissatisfaction. This theory considered reward not only as an economic remuneration, but also as a wide range of results (recognition, promotion, valuation of superiors, etc.).

Petrescu and Simmons (2008) studied the relationship between human resources management and workers' satisfaction with remuneration. They focused on the impact of overall job satisfaction and satisfaction associated with pay. Singh and Loncar (2010) examined the relationship between satisfaction with wages, satisfaction with employment, and change of employment. The study results by Tremblay et al. (2012) demonstrated that family motivations and those related to professional development had a positive effect on satisfaction, and that the motivation to work towards good economic conditions was not enough. Casas et al. (2002) established that the salary was one of the most valued aspects of a job, and for these authors, stability in the workplace implied a positive relationship with job satisfaction as well as an organization commitment.

Organizations may be less motivated to provide good working conditions for temporary workers because they are not the organizational core. This understanding implies that their job satisfaction may be lower than that of permanent workers (Wagenaar et al. 2012). SánchezSellero et al. (2017) studied the lack of job stability in the Spanish economic crisis that began in 2008, as well as the degree of job satisfaction of salaried workers. They found that temporary workers had lower levels of satisfaction than those with permanent contracts, although, from 2008, the satisfaction average increased slightly for both kinds of workers. This result was explained by the high unemployment rate. Thus, any employed worker was considered lucky to be employed and their level of demand for having a job decreased even if employed as a temporary employee. 
According to Westover (2012), job satisfaction was a dynamic concept. In this sense, time and context were useful for a better examination and understanding of the main factors that affected job satisfaction. For this reason, this study proposed the analysis of job satisfaction in the forestry, wood, and paper industries, and compared the results with the Spanish national data.

In a study of job satisfaction, Erol (2016) stated that forestry workers had responsibilities, such as ecological management, sustainability, balance, and social responsibilities that demanded satisfaction, in addition to income generation. Moreover, the lack of motivation of young people to start a professional career in this sector was a threat to the future of the forestry sector. An additional paper about job satisfaction in furniture manufacturing companies was made by Lorincová et al. (2016a). Jelačić et al. (2010) and Lorincová et al. (2016b) conducted an analysis of the motivational factors in wood industry firms. Hitka et al. (2014) and Kropivšek et al. (2011) studied the impact of the economic crisis on the changes in job motivation within the wood industry.

One of the objectives of this paper is to analyze the current Spanish labor market, affected by a longterm economic crisis with high job destruction. It compared the data of the logging, wood, and paper industries with the Spanish national set to find the determinants that most notably influenced job satisfaction. This study considered DScurrentjob as the dependent variable, and a set of variables that measured the degree of subjective satisfaction with labor issues (motivation, activity, salary, etc.) as independent variables. Thus, this paper answered the following questions: What variables affected the degree of satisfaction with one's current job more than others? What was considered to be more important: degree of satisfaction with one's salary, degree of satisfaction with one's activity, or degree of satisfaction with the valuation by one's superiors?

\section{MATERIALS AND METHODS}

\section{MATERIJALI I METODE}

\subsection{Materials}

2.1. Materijali

This study used data from the 2010 Quality of Labor Life Survey (Encuesta de calidad de vida en el trabajo - ECVT), administered by the Spanish Ministry of Employment and Social Security (2010 is the last available data in 2017) (Spain). Our idea was to explain the degree of satisfaction with current work based on several independent variables.

The geographical scope of this survey was Spain as a whole country, except for the cities of Ceuta and Melilla. The population consisted of workers aged 16 years and over residing in family dwellings.

The ECVT sample was designed using stratified three-stage sampling. First, the data was collected only from workers employed in activities that corresponded to sections 02,16 , and 17 of the Clasificación Nacional de Actividades Económicas (National Classification of Eco- nomic Activities in 2009) (CNAE 2009); in other words, forestry and logging, wood and cork industry, (except furniture), straw, and plating and paper industry. The results were compared with the Spanish national set.

The ECVT sample included 8,061 people, out of $18,409,625$ people of the whole Spanish population, but by eliminating the lack of response to some questions, it was narrowed down to 5,841 people. Once the cases were filtered and weighted corresponding to the logging, wood, and paper industries, they represented 136,153 workers.

\subsection{Methods}

\subsection{Metode}

Figure 1 describes the variables used. All of these variables have values from 0 to 10 , where 0 presents a very low level of satisfaction, while 10 presents a high level of satisfaction (see Figure 1).

Job-related features were considered based on the type of contract, working day, hours worked, etc. Thus, the degree of satisfaction with salary could be considered a personal-related feature, because it depended on each person. For instance, two people could have different levels of satisfaction with salary even though they received the same salary. Age and gender were also usually considered personal-related features. They could be considered job-related features because they referred to a personal perception of job-related features such as salary, organization, activity, etc.

Principal component analysis and cluster analysis are methods of grouping variables. Principal component analysis (PCA) allows grouping of 14 independent variables into homogeneous groups, thus constructing new variables, with mean 0 and variance 1 , as a result of previous groups. This method is used to transform a set of variables (interrelated original variables), in a set of variables, linear combination of the original, called principal components (or factors). So, principal component variables are typically uncorrelated with each other, and they can also be organized

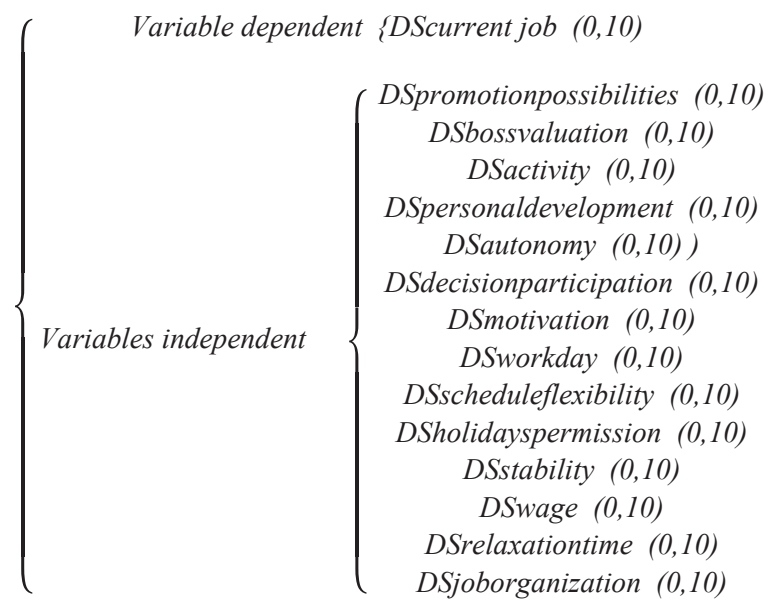

Figure 1 Descriptors of variables and scale (elaboration from the ECVT - Ministry of Employment and Social Security, 2010)

Slika 1. Opisnice varijabli i ljestvica (napravljeno na temelju ECVT-a - Ministarstvo zapošljavanja i socijalne sigurnosti, 2010.) 
according to their own information. Dunteman (1989) proposes variance as a measure of the incorporated information in a component. This process can continue until there are as many components as variables. The first few principal components usually represent the biggest variation in variables.

A cluster analysis is a statistical method for dividing variables into groups based on their similarity (Bryant, 2000). This study attempted to find the greatest homogeneity in each group and the greatest heterogeneity between groups. Previously, the variables were typified to compare them, as suggested by previous literature. It was advised to perform a model with standardized variables (De la Fuente, 2011).

In order to obtain clusters in a hierarchical classification, groups are merged according to a priority or hierarchy and are based on distances between elements or variables. Hierarchical methods are agglomerative (ascending) if they successively merge larger groups in each step. As groups form, they are less homogeneous (the distances between initial groups are smaller than between final groups). The Ward method minimizes intra-group variation. This is one of the most used grouping methods. The representation of the hierarchy of groups is usually done through a diagram called "dendrogram". It reports successive mergers of groups into groups of higher level with higher and lower homogeneity. Variables are represented on vertical axis and distances on horizontal axis.

This study used the stepwise multiple linear regression method, a method also studied by Derksen and Keselman (1992) and Thompson (2001), among others. The method organized variables in a hierarchy, trying to know the relevant variables in a lot of possible independent variables. The stepwise regression with the extracted factors (new variables) of the principal component analysis (PCA) was performed. The models were improved by incorporating factors, as the sum of squares of the regression increases in different steps, while the sum of squared residuals decreases.

\section{RESULTS AND DISCUSSION}

3. REZULTATI I RASPRAVA

Table 1 shows the means of 15 variables mentioned (a dependent variable and 14 independent variables). The degree of satisfaction with salary, DSwage, was the second variable with the lowest mean, because of the effect of the Spanish economic crisis. DSpromotionpossibilities was the variable that produced less satisfaction in the logging, wood and paper industries as a national set.

\subsection{Hypothesis 1: Job-related variables having influence on job satisfaction were classified in homogeneous groups}

3.1. Hipoteza 1: Varijable povezane s poslom koje su utjecale na zadovoljstvo radnika poslom klasificirane su u homogene grupe

To test Hypothesis 1, this study included only job-related variables because they better explained job satisfaction. First, groupings were made between related variables. A principal component analysis (PCA) was used to group independent variables in homogeneous groups, and new variables from the previous groupings were constructed, with a mean of 0 and a variance of 1 .

Table 1 Descriptive statistics and variations with respect to the national set (job-related variables)

Tablica 1. Deskriptivna statistika i varijacije u odnosu prema nacionalom skupu podataka (varijable vezane za posao)

\begin{tabular}{|c|c|c|c|c|c|}
\hline \multirow[t]{2}{*}{$\begin{array}{l}\text { Variables } \\
\text { Varijable }\end{array}$} & \multicolumn{2}{|c|}{$\begin{array}{c}\text { Logging } \\
\text { Wood industry } \\
\text { Paper industry } \\
\text { Radnici u iskorištavanju šuma, } \\
\text { drvnoj i papirnoj industriji }\end{array}$} & \multicolumn{2}{|c|}{$\begin{array}{c}\text { Spanish } \\
\text { population } \\
\text { Španjolsko stanovništvo }\end{array}$} & \multirow{2}{*}{\begin{tabular}{|} 
Increments or \\
decreases compared \\
with the national \\
mean \\
Povećanje ili \\
smanjenje u uspored- \\
bi s nacionalnim \\
prosjekom
\end{tabular}} \\
\hline & $\begin{array}{c}\text { Mean } \\
\text { Srednja } \\
\text { vrijednost }\end{array}$ & $\begin{array}{c}\text { Standard } \\
\text { Deviation } \\
\text { Standardna devi- } \\
\text { jacija }\end{array}$ & \begin{tabular}{|} 
Mean \\
Srednja \\
vrijednost
\end{tabular} & $\begin{array}{c}\text { Standard } \\
\text { Deviation } \\
\text { Standardna } \\
\text { devijacija }\end{array}$ & \\
\hline DScurrentjob & 7.6 & 1.45601 & 7.4 & 1.81885 & $(+)$ \\
\hline DSpromotionpossibilities & 5.3 & 3.46425 & 5.2 & 3.19625 & $(+)$ \\
\hline DSbossvaluation & 7.7 & 1.53162 & 7.2 & 2.18227 & $(+)$ \\
\hline DSactivity & 7.8 & 1.42380 & 7.8 & 1.78792 & $(=)$ \\
\hline DSpersonaldevelopment & 7.6 & 1.90947 & 7.6 & 1.98172 & $(=)$ \\
\hline DSautonomy & 7.3 & 2.10119 & 7.5 & 2.22668 & $(-)$ \\
\hline DSdecisionparticipations & 6.5 & 2.67007 & 6.9 & 2.62675 & $(-)$ \\
\hline DSmotivation & 6.9 & 2.43171 & 7.2 & 2.32801 & $(-)$ \\
\hline DSworkday & 7.6 & 1.60609 & 7.1 & 2.34677 & $(+)$ \\
\hline DSscheduleflexibility & 6.6 & 3.17289 & 6.5 & 3.09382 & $(+)$ \\
\hline DSholidays.permissions & 7.5 & 2.51057 & 7.1 & 2.69060 & $(+)$ \\
\hline DSstability & 6.9 & 2.71186 & 7.1 & 2.75592 & $(-)$ \\
\hline DSwage & 6.2 & 2.36568 & 5.8 & 2.41210 & $(+)$ \\
\hline DSrelaxationtime & 6.5 & 2.78229 & 6.7 & 2.63654 & $(-)$ \\
\hline DSjoborganization & 7.4 & 1.76960 & 7.1 & 2.19004 & $(+)$ \\
\hline
\end{tabular}

*Note: the dependent variable was DScurrentjob; (elaboration from the ECVT - Ministry of Employment and Social Security, 2010) / Zavisna varijabla bila je DScurrentjob (napravljeno na temelju ECVT-a-Ministarstvo zapošljavanja i socijalne sigurnosti, 2010.) 


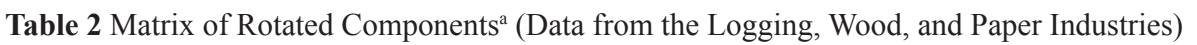

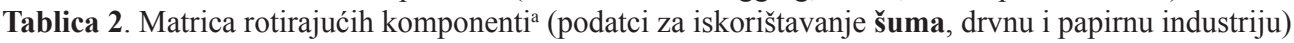

\begin{tabular}{|l|c|c|c|c|c|c|}
\hline \multirow{2}{*}{$\begin{array}{c}\text { Variables } \\
\text { Varijable }\end{array}$} & \multicolumn{7}{c|}{ Component / Komponenta } \\
\cline { 2 - 7 } & 1 & 2 & 3 & 4 & 5 & 6 \\
\hline DSmotivation & $\mathbf{0 . 8 5 2}$ & 0.126 & 0.085 & -0.024 & -0.031 & 0.001 \\
\hline DSjoborganization & $\mathbf{0 . 8 3 0}$ & 0.130 & -0.041 & 0.008 & 0.287 & 0.091 \\
\hline DSpersonaldevelopment & $\mathbf{0 . 5 6 2}$ & 0.435 & 0.131 & 0.249 & -0.511 & 0.134 \\
\hline DSbossvaluation & $\mathbf{0 . 5 3 4}$ & 0.319 & 0.491 & 0.280 & -0.142 & 0.175 \\
\hline DSautonomy & 0.038 & $\mathbf{0 . 9 1 7}$ & -0.013 & 0.096 & -0.162 & 0.007 \\
\hline DSdecisionparticipations & 0.276 & $\mathbf{0 . 8 2 9}$ & -0.034 & 0.047 & 0.308 & 0.018 \\
\hline DSpromotionpossibilities & 0.168 & $\mathbf{0 . 6 0 7}$ & 0.240 & -0.023 & -0.024 & 0.577 \\
\hline DSactivity & 0.467 & $\mathbf{0 . 6 0 0}$ & 0.255 & 0.147 & 0.075 & 0.084 \\
\hline DSworkday & 0.096 & 0.019 & $\mathbf{0 . 8 4 5}$ & 0.096 & 0.216 & 0.217 \\
\hline DSscheduleflexibility & 0.280 & 0.419 & $\mathbf{0 . 6 1 0}$ & 0.256 & -0.010 & -0.277 \\
\hline DSholidays.permissions & -0.035 & 0.187 & 0.274 & $\mathbf{0 . 8 5 5}$ & 0.108 & -0.198 \\
\hline DSstability & 0.423 & 0.190 & 0.033 & $\mathbf{0 . 7 4 5}$ & 0.034 & 0.352 \\
\hline DSrelaxationtime & 0.276 & 0.125 & 0.302 & 0.200 & $\mathbf{0 . 8 0 4}$ & 0.069 \\
\hline DSwage & 0.507 & 0.138 & 0.122 & 0.015 & 0.062 & $\mathbf{0 . 7 0 0}$ \\
\hline
\end{tabular}

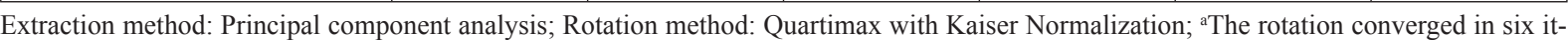
erations (elaboration from the ECVT - Ministry of Employment and Social Security, 2010) /

Metoda izlučivanja: analiza glavne komponente; metoda rotacije: Quartimax s Kaiserovom normalizacijom; ${ }^{a}$ rotacija se konvergira $u$ šest iteracija (napravljeno na temelju ECVT-a - Ministarstvo zapošljavanja i socijalne sigurnosti, 2010.)

The determinant of the correlation matrix of variables was almost zero and the Kaiser-Meyer-Olkin (KMO) measure was higher than 0.500 (this was good). The Bartlett test had a $p$-value equal to zero and lower than 0.05 , which allowed the rejection of the hypothesis of the identity matrix. A previous PCA study of job satisfaction was conducted by Platis et al. (2015) and Leung et al. (2015).

Six factors (new variables) were extracted through the Quartimax rotation system. This is an orthogonal alternative, which minimizes the number of factors needed to explain each variable. In addition, the coefficients were ordered by size. Thus, the percentage of explained variability by the extracted factors was 81 $\%$. The matrix of rotated components is shown in Table 2 . These factors had a mean of zero and a standard deviation of one, and they were uncorrelated with one another. DSwage was not grouped with any other variable. A high association was found between the initial variables, because the saturations were higher than 0.500 .

These 14 variables were summarized into six new factors. Factor 1 was the degree of satisfaction with motivation, job organization, personal development, and superiors' valuation. Factor 2 included autonomy, participation in decisions, possibility of promotion, and activity. Factor 3 considered the working day and schedule flexibility. Factor 4 contained stability, holidays, and leaves; factor 5 considered rest time; and factor 6 considered salary. Sánchez-Sellero and Sánchez-Sellero (2016) performed the same study with the Spanish set. Some factors were the same, such as the factor for salary, another for holidays, leaves, and stability, and another for schedule flexibility, working day, and rest time. These variables were logically associated. The variable of holidays and leaves was grouped with stability because some unstable and short-term jobs did not generate vacation entitlement. However, the minimum number of items in each factor was to be three, which according to Costello and Osborne (2005), presents one of the requirements for "clean" factor structure (see both groups in Table 3).

Figure 2 shows a cluster analysis through a hierarchical cluster analysis and Ward's method applied to the data of the logging, wood, and paper industries. This study applied the same methodology with the data of the Spanish set in Fig. 2. Both figures (A and B) have more similarities than differences. Activity and personal development form one of the groups, and autonomy and participation in decisions form another. These two groups were the most homogeneous because the variables were the closest, i.e., the distances were the smallest in the upper axis. The number of clusters can be counted with much subjectivity. In this case, 5 clusters (indicated on the left of the graph) were considered for the group of wood and paper industry, because the distances on the right of a hypothetical vertical line marked in Figure 2.A are much larger. It is difficult to name the clusters because in this case all variables are job-related features. Faletar et al. (2016) applied the same methodology in wood firms. Some other papers about satisfaction applied a cluster analysis, such as Błachnio et al. (2016) and Van Aerden et al. (2016). It should be noted that Van Aerden et al. (2016) used the data from the Quality of Labor Life Survey in European countries.

\subsection{Hypothesis 2: Motivation, activity, and personal development were the most influential variables in job satisfaction}

3.2. Hipoteza 2: Varijable motivacija, aktivnost i osobni razvoj najviše su utjecale na zadovoljstvo poslom

In addition, a stepwise regression with factors extracted from the principal component analysis (PCA) was applied to verify Hypothesis 2. SánchezSellero and Sánchez-Sellero (2016) performed the same study with data from the Spanish set over a period of three years. A regression analysis performed 
Table 3 Factors obtained from principal component analysis, variables in the logging, wood and paper industries compared with variables in the Spanish set

Tablica 3. Faktori dobiveni iz analize glavnih komponenata; usporedba skupa varijabli za iskorištavanje šuma, drvnu i papirnu industriju sa skupom varijabli za ukupno španjolsko tržište rada

\begin{tabular}{|c|c|c|c|}
\hline & $\begin{array}{c}\text { Variables: } \\
\text { Logging, wood, and paper industries } \\
\text { Varijable: } \\
\text { iskorištavanje šuma, drvna i papirna industrija }\end{array}$ & & $\begin{array}{l}\text { Variables: } \\
\text { Spanish Set } \\
\quad \text { Varijable: } \\
\text { španjolski skup }\end{array}$ \\
\hline Factor 1 & $\begin{array}{l}\text { DSmotivation } \\
\text { DSjoborganization } \\
\text { DSpersonaldevelopment } \\
\text { DSbossvaluation }\end{array}$ & Factor 1 & $\begin{array}{c}\text { DSactivity } \\
\text { DSpersonaldevelopment } \\
\text { DSmotivation }\end{array}$ \\
\hline Factor 2 & $\begin{array}{c}\text { DSautonomy } \\
\text { DSdecisionparticipations } \\
\text { DSpromotionpossibilities } \\
\text { DSactivity }\end{array}$ & Factor 2 & $\begin{array}{l}\text { DSscheduleflexibility } \\
\text { DSrelaxationtime } \\
\text { DSworkday }\end{array}$ \\
\hline & $\begin{array}{l}\text { Less than three variables by each factor } \\
\text { manje od tri varijable za svaki faktor }\end{array}$ & Factor 3 & $\begin{array}{c}\text { DSpromotionpossibilities } \\
\text { DSbossvaluation } \\
\text { DSjoborganization } \\
\end{array}$ \\
\hline Factor 3 & $\begin{array}{c}\text { DSworkday } \\
\text { DSscheduleflexibility }\end{array}$ & \multicolumn{2}{|c|}{$\begin{array}{l}\text { Less than three variables by each factor } \\
\text { manje od tri varijable za svaki faktor }\end{array}$} \\
\hline Factor 4 & $\begin{array}{c}\text { DSholidays.permissions } \\
\text { DSstability }\end{array}$ & Factor 4 & $\begin{array}{c}\text { DSstability } \\
\text { DSholidays.permissions }\end{array}$ \\
\hline Factor 5 & DSrelaxationtime & Factor 5 & $\begin{array}{c}\text { DSdecisionparticipations } \\
\text { DSautonomy }\end{array}$ \\
\hline Factor 6 & DSwage & Factor 6 & DSwage \\
\hline
\end{tabular}

${ }^{a}$ This column is the result of Sánchez-Sellero and Sánchez-Sellero (2016) / Taj je stupac rezultat rada Sánchez-Sellero and Sánchez-Sellero (2016.) (elaboration from the ECVT (Ministry of Employment and Social Security, 2010) / (napravljeno na temelju ECVT-a - Ministarstvo zapošljavanja i socijalne sigurnosti, 2010.)

through the factors extracted from a PCA can also be seen in Aizawa et al. (2015). This regression method was useful to explain a dependent variable (in this case DScurrentjob) from several potential independent variables (predictors) in the case that there was no theory that allowed the advance selection of a subset of predictors to evaluate the model. Thus, this study attempted to select a set of variables that contributed significantly ( $p$-value $<0.01)$ to the model. Only variables that were significant predictors of job satisfaction were included. The same methodology was applied to the job field by Senise Barrio and Lloréns Montes (1996), and García Sedeño et al. (2003), among others. Goetz et al. (2015) proposed a stepwise regression model in the field of job satisfaction, although with different variables.
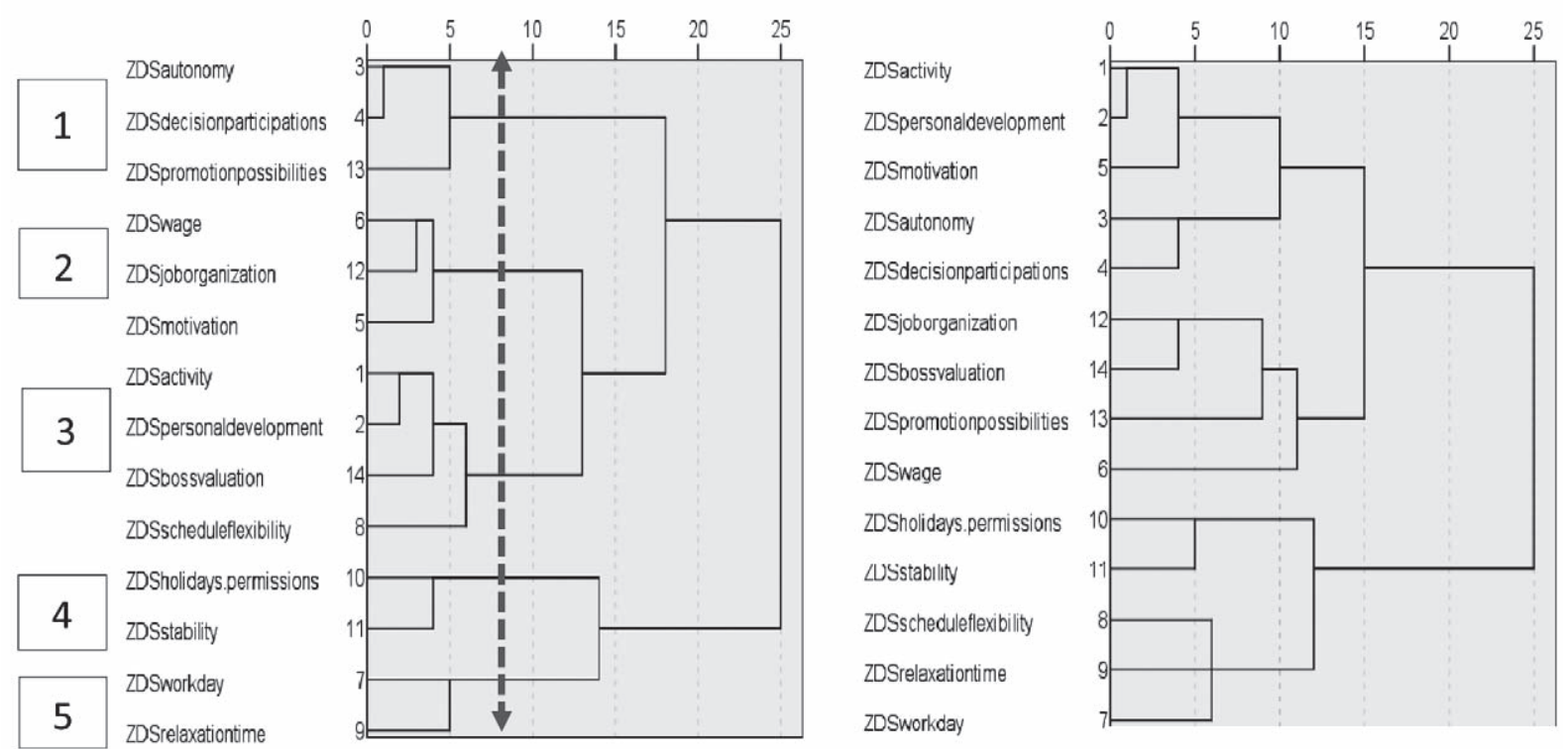

A)

B)

Figure 2 A) Dendrogram using Ward's Linkage, a group combination of rescaled distance (Data from the Logging, Wood, and Paper Industries); B) Dendrogram using Ward's linkage, group combination of rescaled distance (Data from the Spanish Set) Slika 2. A) Dendrogram primjenom Wardove metode, kombinacije skupina na temelju izmjerene udaljenosti (podatci iz djelatnosti iskorištavanja šuma te drvne i papirne industrije); B) dendrogram primjenom Wardove metode, kombinacije skupina na temelju izmjerene udaljenosti (podatci iz nacionalne baze podataka) 
Table 4 Summary of stepwise regression models obtained from the principal component analysis factors ${ }^{\mathrm{g}}$

Tablica 4. Sažetak modela postupne regresije dobivenih od faktora analize glavnih komponenata

\begin{tabular}{|c|c|c|c|c|c|c|c|c|c|}
\hline \multicolumn{10}{|c|}{ Logging, wood and paper industries / Iskorištavanje šuma, drvna i papirna industrija } \\
\hline \multirow[t]{2}{*}{ Model } & \multirow[t]{2}{*}{$\mathrm{R}$} & \multirow[t]{2}{*}{$R^{2}$} & \multirow{2}{*}{$\begin{array}{c}\text { Corrected } \\
R^{2}\end{array}$} & \multirow{2}{*}{$\begin{array}{c}\text { Standard } \\
\text { Deviation }\end{array}$} & \multicolumn{5}{|c|}{ Statistics of change / Statistika promjene } \\
\hline & & & & & $\begin{array}{c}\text { Change in } \\
R^{2}\end{array}$ & $\begin{array}{c}\text { Change } \\
\text { in } F\end{array}$ & gl1 & gl2 & $\begin{array}{l}\text { Significant } \\
\text { change in } F\end{array}$ \\
\hline 1 & $0.537^{\mathrm{a}}$ & 0.288 & 0.288 & 1.16288 & 0.288 & 45152.693 & 1 & $\mathbf{1 1 1 , 5 6 6}$ & 0.000 \\
\hline 2 & $0.691^{b}$ & 0.477 & 0.477 & 0.99691 & 0.189 & 40243.482 & 1 & 111,565 & 0.000 \\
\hline \multicolumn{10}{|c|}{ Introducing the other factors / Uvođenje novih faktora } \\
\hline 3 & $0.705^{\mathrm{c}}$ & 0.497 & 0.497 & 0.97749 & 0.020 & 4477.027 & 1 & 111,564 & 0.000 \\
\hline 4 & $0.711^{\mathrm{d}}$ & 0.506 & 0.506 & 0.96879 & 0.009 & 2014.616 & 1 & 111,563 & 0.000 \\
\hline 5 & $0.713^{\mathrm{e}}$ & 0.508 & 0.508 & 0.96707 & 0.002 & 397.211 & 1 & 111,562 & 0.000 \\
\hline 6 & $0.713^{\mathrm{f}}$ & 0.508 & 0.508 & 0.96698 & 0.000 & 22.610 & 1 & 111,561 & 0.000 \\
\hline \multicolumn{10}{|c|}{ Spanish Set / Španjolska nacionalna baza podataka } \\
\hline \multirow[t]{2}{*}{ Model } & \multirow[t]{2}{*}{$\mathrm{R}$} & \multirow[t]{2}{*}{$R^{2}$} & \multirow{2}{*}{$\begin{array}{c}\text { Corrected } \\
R^{2}\end{array}$} & \multirow{2}{*}{$\begin{array}{l}\text { Standard } \\
\text { deviation }\end{array}$} & \multicolumn{5}{|c|}{ Statistics of change / Statistika promjene } \\
\hline & & & & & $\begin{array}{c}\text { Change in } \\
R^{2}\end{array}$ & $\begin{array}{l}\text { Change } \\
\text { in } F\end{array}$ & gl1 & g12 & $\begin{array}{l}\text { Significant } \\
\text { Change in } F\end{array}$ \\
\hline 1 & $0.615^{\mathrm{a}}$ & 0.379 & 0.379 & 1.39223 & 0.379 & $8,356,032.222$ & 1 & $13,701,262$ & 0.000 \\
\hline 2 & $0.687^{b}$ & 0.472 & 0.472 & 1.28406 & 0.093 & $2,405,825.898$ & 1 & $13,701,261$ & 0.000 \\
\hline \multicolumn{10}{|c|}{ Introducing the other factors / Uvođenje novih faktora } \\
\hline 3 & $0.737^{\mathrm{c}}$ & 0.543 & 0.543 & 1.19413 & 0.071 & $2,141,265.884$ & 1 & $13,701,260$ & 0.000 \\
\hline 4 & $0.768^{\mathrm{d}}$ & 0.589 & 0.589 & 1.13204 & 0.046 & $1,544,262.917$ & 1 & $13,701,259$ & 0.000 \\
\hline 5 & $0.788^{\mathrm{e}}$ & 0.621 & 0.621 & 1.08801 & 0.031 & $1,131,339.509$ & 1 & $13,701,258$ & 0.000 \\
\hline 6 & $0.794^{\mathrm{f}}$ & 0.630 & 0.630 & 1.07476 & 0.009 & $339,948.845$ & 1 & $13,701,257$ & 0.000 \\
\hline
\end{tabular}

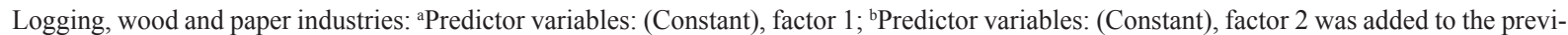
ous ones; 'Predictor variables: (Constant), factor 4 was added to the previous ones; ${ }^{d}$ Predictor variables: (Constant), factor 3 was added to the previous ones; ${ }^{\mathrm{P} P r e d i c t o r}$ variables: (Constant), factor 5 was added to the previous ones; ${ }^{\mathrm{f}}$ Predictor variables: (Constant), factor 6 was added to the previous ones

Spanish Set: aPredictor variables: (Constant), factor 1; ${ }^{b}$ Predictor variables: (Constant), factor 3 was added to the previous ones; ${ }^{\mathrm{c} P r e d i c t o r}$ variables: (Constant), factor 2 was added to the previous ones; ${ }^{\mathrm{d}}$ Predictor variables: (Constant), factor 4 was added to the previous ones; ${ }^{\mathrm{e} P r e d i c-}$ tor variables: (Constant), factor 6 was added to the previous ones; 'Predictor variables: (Constant), factor 5 was added to the previous ones; 'Dependent variable: DScurrentjob

(elaboration from ECVT - Ministry of Employment and Social Security, 2010)

This study included a variable into the model if the critical level associated with its partial correlation coefficient was less than 0.05 in an independent hypothesis (probability of entry), according to the stepwise method. The variable stayed out of the model if that critical level was greater than 0.10 (probability of exit). Table 4 shows a summary of the stepwise regression models derived from the PCA factors. It collected the $R$ and $R^{2}$ in each step. The standard deviation decreased (1.16288 to 0.96698 with data from the logging, wood, and paper industries). One way to estimate the effect of applying these selection criteria was to observe the change in $R^{2}$ as variables were added to the model. A big change in $\mathrm{R}^{2}$ indicated that this variable (in this case factor 1) contributed noticeably to explain the dependent variables. The F-statistic and its critical level contrasted the hypothesis that the change in $R^{2}$ was zero in the population. The six independent variables (the PCA factors) explained 50.8 $\%$ of the variable variance DScurrentjob. A model with all factors or only with factors formed by 3 or more variables can be proposed. It has been verified that the factors that contribute the highest percentage of explanation to DScurrentjob variable correspond to these first factors obtained from PCA analysis (see Table 4).

The model improved when the factors were introduced because the sum of squares of the regression increased, whereas the residual sum of squares decreased. Factor 1 had the greatest influence on job satisfaction in both data sets in the stepwise regression made with the above factors (Table 4). In terms of explanation degree, the wage factor (factor 6) was the last, or penultimate, in both models. Factor 1 was motivation, personal development, job organization, and superiors' valuation in the logging, wood, and paper industries, and it included motivation, personal development, and activity in the Spanish set.

These significant contributions to the literature were based on a cross-sectional study. Longitudinal studies can be carried out to more accurately describe the subject.

\section{CONCLUSION 4. ZAKLJUČAK}

This study contributed to the understanding of job satisfaction through a combination of different statistical methodologies and a comparative analysis of the results in the logging, wood, and paper industries and those in the national Spanish set, and explained the differences and similarities between them.

All in all, the degrees of satisfaction were high because all of them were in the range of six to seven points on a scale from zero to ten. The degree of satisfaction with salary was one of the variables valued low. The reason may be in the reduction of workers' salary during the Spanish economic crisis.

Workers in the logging, wood, and paper industries evaluated the lowest their satisfaction with the 
possibility of promotions, which was also a possible consequence of the Spanish economic crisis. Although recently there has been no survey, it is believed that satisfaction with wages and the possibility of promotions will recover as a result of the current economic recovery.

Many coincidences were found in the homogeneous groups of variables that affected the job satisfaction between the logging, wood, and paper industries and the Spanish set. These appeared in the following groups: motivation and personal development; stability, holidays, and autonomy; and participation in decisions. These groups were coherent in their explanation. Salary was included in a separate group.

A principal component analysis showed in both groups (the logging, wood, and paper industries and the Spanish set) that the group with the greatest influence on job satisfaction was motivation and personal development, whereas salary was the one with the lowest influence (explanation percent).

The stepwise regression shows the first factors obtained in PCA analysis, which explain better satisfaction with current work and contribute to the goodness of the model (the greater R-squared). The said first factors are formed by three or more variables. The other factors also explain this variable but in a smaller percentage. It should be noted that the hierarchy established in the PCA analysis is basically maintained in the stepwise regression, so that factor 1 (motivationpersonal development) is consolidated as the first group of variables of greater relevance in the explanation of job satisfaction.

Based on this study, it can be concluded that behavioral patterns about job satisfaction in logging, wood, and paper industries, are very similar to the Spanish set and that job satisfaction is extremely important.

Previous literature considered that job satisfaction had a positive correlation with job performance. As a consequence, firms and institutions should try to improve the satisfaction of their workforce. Thus, workers need to be motivated to improve their satisfaction.

\section{Acknowledgement - Zahvala}

This study was supported by projects ECO201677843-P (AEI/FEDER, UE) and S125: Compete Research Group (DGA/FEDER, UE).

\section{REFERENCES}

\section{LITERATURA}

1. Aizawa, F.; Kishi, M.; Aizawa, Y.; Hirata, S.; Ishii, T.; Yonemitsu, M., 2015: Targeting individual empowerment to raise leaders for local oral health promotion in Japan. Asia Pacific Journal of Public Health, 27 (2): 2305-2315. https://doi.org/10.1177/1010539511428669.

2. Alnıaçık, Ü.; Alnıaçık, E.; Akçin, K.; Erat, S., 2012: Relationships between career motivation, affective commitment, and job satisfaction. Procedia- Social and Behavioral Sciences, 58: 355-362.

https://doi.org/10.1016/j.sbspro.2012.09.1011.
3. Błachnio, A.; Przepiorka, A.; Pantic, I., 2016: Association between Facebook addiction, self-esteem, and life satisfaction: A cross-sectional study. Computers in $\mathrm{Hu}-$ man Behavior, 55 (Part B): 701-705.

https://doi.org/10.1016/j.chb.2015.10.026.

4. Bòria-Reverter, S.; Crespi-Vallbona, M.; MascarillaMiró, O., 2012: Variables determinantes de la satisfacción laboral en España (Variables determining labor satisfaction in Spain). Cuadernos de Economía, 35 (97): 9-16. https://doi.org/10.1016/S0210-0266(12)70018-3.

5. Bryant, F. B., 2000: Assessing the validity of measurement. In: Reading and Understanding MORE Multivariate Statistics, P. R. Yarnold, L. G. Grimm (eds.). American Psychological Association, Washington, D.C., pp. 99-146.

6. Casas, J.; Repullo, J. R.; Lorenzo, S.; Cañas, J. J., 2002: Dimensiones y medición de la calidad de vida laboral en profesionales sanitarios (Scope and measurement of quality of job life in health professionals). Revista de Administración Sanitaria, 6 (23): 143-160.

7. Cequea, M.; Nuñez Bottini, M., 2011: Factores humanos y su influencia en la productividad (Human factors and their influence on productivity). Revista Venezolana de Gerencia, 16 (53): 116-137.

8. Chiang Vega, M.; Martín Rodrigo, M. J.; Núñez Partido, A., 2010: Relaciones entre el clima organizacional y la satisfacción laboral (Relations Between Organizational Climate and Job Satisfaction). Universidad Pontificia Comillas, Madrid, Spain.

9. Costello, A. B.; Osborne, J. W., 2005: Best practices in exploratory factor analysis: Four recommendations for getting the most from your analysis. Practical assessment, research \& evaluation, 10 (7): 1-9.

10. Cuadra-Peralta, A. A.; Veloso-Besio, C. B., 2010: Grado de supervisión como variable moderadora entre liderazgo y satisfacción, motivación y clima organizacional (Degree of supervision as a moderating variable between leadership and satisfaction, motivation and organizational climate). Ingeniare- Revista Chilena de Ingeniería, 18 (1): $15-25$.

11. De la Fuente, S., 2011: Análisis Conglomerados (Conglomerate Analysis). Facultad de Ciencias Económicas y Empresariales, Universidad Autónoma de Madrid, Madrid, Spain.

12. Derksen, S.; Keselman, H. J., 1992: Backward, forward, and stepwise automated subset selection algorithms: Frequency of obtaining authentic and noise variables. British Journal of Mathematical and Statistical Psychology, 45 (2): 265-282.

https://doi.org/10.1111/j.2044-8317.1992.tb00992.x.

13. Dueñas, D.; Iglesias, C.; Llorente, R., 2010: Job quality, job satisfaction, and services in Spain. Journal of Innovation Economics and Management, 1 (5), 145-166. https://doi.org/10.3917/jie.005.0145.

14. Dunteman, G. H. 1989: Main components analysis (No. 69). Sage

15. Erol, S. Y., 2016: Comprehensive analysis of some jobrelated attitudes on expectation and satisfaction among forestry staff: Case results from a Turkish regional forestry organization. International Forestry Review, 18 (2): 161-179. https://doi.org/10.1505/146554816818966309.

16. Faletar, J.; Jelačić, D.; Sedliačiková, M.; Jazbec, A.; Hajdúchová, I., 2016: Motivating employees in a wood processing company before and after restructuring. BioResources, 11 (1): 2504-2515.

https://doi.org/10.15376/biores.11.1.2504-2515. 
17. García Sedeño, M. A.; Barbero García, M. I.; Ávila Carretero, I.; García Tejera, M. C., 2003: La motivación laboral de los jóvenes en su primer empleo (The work motivation of young people in their first job). Psicothema, 15 (1): 109-113.

18. Goetz, K.; Hasse, P.; Campbell, S. M.; Berger, S.; Dörfer, C. E.; Hahn, K.; Szecsenyi, J., 2015: Evaluation of job satisfaction and working atmosphere of dental nurses in Germany. Community Dentistry and Oral Epidemiology, 44 (1): 24-31. https://doi.org/10.1111/cdoe.12186.

19. Grant, A. M.; Sumanth, J. J., 2009: Mission possible? The performance of prosocially motivated employees depends on manager trustworthiness. Journal of Applied Psychology, 94 (4): 927-944. https://doi.org/10.1037/a0014391.

20. Guest, D.; Conway, N., 2002: Communicating the psychological contract: An employer perspective. Human Resource Management Journal, 12 (2): 22-38. https://doi.org/10.1111/j.1748-8583.2002.tb00062.x.

21. Hitka, M.; Hajduková, A.; Balážová, Ž., 2014: Impact of economic crisis on changes in motivation of employees in woodworking industry. Drvna industrija, 65 (1): 21 26. https://doi.org/10.5552/drind.2014.1303.

22. Hoppock, R., 1935: Job Satisfaction. Harper and Brothers, New York.

23. Jelačić, D.; Grladinović, T.; Pirc, A.; Oblak, L., 2010: Motivation factors analysis in industrial plants. Strojarstvo, 52 (3): 349-361.

24. Judge, T. A.; Thoresen, C. J.; Bono, J. E.; Patton, G. K., 2001: The job satisfaction-job performance relationship: A qualitative and quantitative review. Psychological Bulletin, 127 (3): 376-407. https://doi.org/10.1037/0033-2909.127.3.376.

25. Kanfer, R., 1995: Motivation and performance. In: Blackwell Encyclopedic Dictionary of Organizational Behaviour, N. Nicholson (ed.). Wiley-Blackwell, Oxford, England.

26. Kropivšek, J.; Jelačić, D.; Grošelj, P., 2011: Motivating employees of Slovenian and Croatian wood-industry companies in times of economic downturn. Drvna industrija, 62 (2): 97-103. https://doi.org/10.5552/drind.2011.1040.

27. Lawler, E. E., 1973: Motivation in Work Organizations, Brooks / Cole Publishing Co., Monterey, CA, USA.

28. Leung, J.; Rioseco, P.; Munro, P., 2015: Stress, satisfaction, and burnout amongst Australian and New Zealand radiation oncologists. Journal of Medical Imaging and Radiation Oncology, 59 (1): 115-124. https://doi.org/10.1111/1754-9485.12217.

29. Lorincová, S.; Schmidtová, J.; Javorčíková, J., 2016a: Employee Job Satisfaction in Furniture Manufacturing Companies in the Slovak Republic. Drvna industrija, 67 (4): 351-362. https://doi.org/10.5552/drind.2016.1614.

30. Lorincová, S.; Hitka, M.; Čambál, M.; Szabó, P.; Javorčíková, J., 2016b: Motivational factors influencing senior managers in the forestry and wood-processing sector in Slovakia. BioResources, 11 (4): 10339-10348. https://doi.org/10.15376/biores.11.4.10339-10348.

31. Ministry of Employment and Social Security, 2010: Survey of Quality of Life at Work. Madrid, Spain.

32. Pérez, J. A., 1997: Motivación y satisfacción laboral: Retrospectiva sobre sus formas de análisis (Motivation and job satisfaction: Retrospective of their forms of analysis). Revista Española de Investigaciones Sociológicas, 80: 133-167. https://doi.org/10.2307/40183920.

33. Petrescu, A. I.; Simmons, R., 2008: Human resource management practices and workers' job satisfaction. In- ternational Journal of Manpower, 29 (7): 651-667. https://doi.org/10.1108/01437720810908947.

34. Platis, C.; Reklitis, P.; Zimeras, S., 2015: Relation between job satisfaction and job performance in healthcare services. Procedia- Social and Behavioral Sciences, 175: 480-487. https://doi.org/10.1016/j.sbspro.2015.01.1226.

35. Rego, A.; Souto, S.; Pina e Cunha, M., 2009: Does the need to belong moderate the relationship between perceptions of spirit of camaraderie and employees' happiness? Journal of Occupational Health Psychology, 14 (2): 148-164. https://doi.org/10.1037/a0014767.

36. Robles-García, M.; Dierssen-Sotos, T.; Martínez-Ochoa, E.; Herrera-Carral, P.; Díaz-Mendi, A. R.; Llorca-Díaz, J., 2005: Variables relacionadas con la satisfacción laboral: Un estudio transversal a partir del modelo EFQM (Variables related to job satisfaction. Cross-sectional study using the European Foundation for Quality Management [EFQM] model). Gaceta Sanitaria, 19 (2): 127 134. https://doi.org/10.1157/13074368.

37. Sánchez-Sellero, M. C.; Sánchez-Sellero, P.; CruzGonzález, M. M.; Sánchez-Sellero, F. J., 2014: Características organizacionales de la satisfacción laboral en España (Organizational characteristics in the labor satisfaction in Spain). RAE-Revista de Administração de Empresas, 54 (5): 537-547. https://doi.org/10.1590/S0034-759020140507

38. Sánchez-Sellero, M. C.; Sánchez-Sellero, P., 2016: Factores determinantes de la satisfacción laboral en España antes y durante la crisis de 2008 (Determinants of job satisfaction in Spain before and during the economic crisis of 2008). Intangible Capital, 12 (5): 1192-1220. https://doi.org/10.3926/ic.844.

39. Sánchez-Sellero, M. C.; Sánchez-Sellero, P.; CruzGonzález, M. M.; Sánchez-Sellero, F. J., 2017: Stability and satisfaction at work during the Spanish economic crisis. Prague Economic Papers, 26 (1): 72-89. https://doi.org/10.18267/j.pep.596.

40. Senise Barrio, M. E.: Lloréns Montes, F. J., 1996: Una evaluación económica del impacto salarial en las actitudes de los trabajadores ante el mercado laboral (An economic evaluation of wage impact on workers attitudes in labor market). Investigaciones Europeas de Dirección y Economía de la Empresa, 2 (3): 13-26.

41. Shah, S. M.; Zaidi, S.; Ahmed, J.; Rehman, S. U., 2016: Motivation and retention of physicians in primary healthcare facilities: A qualitative study from Abbottabad, Pakistan. International Journal of Health Policy and Management, 5 (8): 467-475. https://doi.org/10.15171/ijhpm.2016.38.

42. Singh, P.; Loncar, N., 2010: Pay satisfaction, job satisfaction, and turnover intent. Relations Industrielles (Industrial Relations), 65 (3): 470-490.

https://doi.org/10.7202/044892ar.

43. Thompson, B., 2001: Significance, effect sizes, stepwise methods, and other issues: Strong arguments move the field. Journal of Experimental Education, 70 (1): 80-93. https://doi.org/10.1080/00220970109599499.

44. Tremblay, M.; Chênevert, D.; Hébert, A., 2012: Le rôle des conditions de travail dans la satisfaction et la loyauté des infirmières d'agence au Québec (The role of working conditions in satisfaction and loyalty of agency nurses in Quebec). Relations Industrielles (Industrial Relations), 67 (3): 477-504. https://doi.org/10.7202/1012540ar

45. Van Aerden, K.; Puig-Barrachina, V.; Bosmans, K.; Vanroelen, C., 2016: How does employment quality relate to 
health and job satisfaction in Europe? A typological approach. Social Science \& Medicine, 158: 132-140. https://doi.org/10.1016/j.socscimed.2016.04.017.

46. Van Der Meer, P. H.; Wielers, R., 2013: What makes workers happy? Applied Economics, 45 (3): 357-368. https://doi.org/10.1080/00036846.2011.602011.

47. Wagenaar, A. F.; Taris, T. W.; Houtman, I. L.; Van den Bossche, S.; Smulders, P.; Kompier, M. A., 2012: Labour contracts in the European Union, 2000-2005: Differences among demographic groups and implications for the quality of working life and work satisfaction. European Journal of Work and Organizational Psychology, 21 (2): 169-194.

https://doi.org/10.1080/1359432X.2010.548121.

48. Westover, J. H., 2012: Comparative welfare state impacts on work quality and job satisfaction: A cross-national analysis. International Journal of Social Economics, 39 (7): 503-525.

https://doi.org/10.1108/03068291211231687.

\section{Corresponding address:}

\section{MARÍA CARMEN SÁNCHEZ-SELLERO,}

Senior Lecturer

Universidade da Coruña

Department of Applied Economics

Faculty of Economics and Business Administration

Campus Elviña

15071, A Coruña, SPAIN

email: c.sanchez@udc.es 